\title{
KADAR PROTEIN TERLARUT DAN GULA TOTAL BISKUIT FUNGSIONAL BERAS JAGUNG (Zea mays I) FERMENTASI
}

\section{[Dissolved Protein and Total Sugar Content of Functional Biscuits Were Carried Out Optionally Fermented Corn Rice (Zea mays I)]}

\author{
Stevi Evalin Mandjoro ${ }^{1 *}$, Nurhaeni ${ }^{1}$, Indriani $^{1}$, Jusman $^{1}$ \\ 1) Jurusan Kimia, Fakultas MIPA, Universitas Tadulako, Palu \\ J. Soekarno Hatta Km.9, Kampus Bumi Tadulako Tondo Palu, Telp. 0451- 422611 \\ *)Coresponding author: Stevimandjoro@yohoo.com(082187178726) \\ Diterima 12 Desember 2018, Disetujui 22 Februari 2019
}

\begin{abstract}
Research on dissolved protein and total sugar content of functional biscuits were carried out optionally fermented corn rice. This study aims are to determine the fermentation time which has the highest levels of dissolved protein and total sugar to functional biscuits. Variation of fermentation time is to determine soluble protein content and total functional biscuit sugar is $(12,24,36,48$ and 60 hours). The results of the analysis obtained is at the time of fermentation for 60 hours with dissolved protein content of $2.274 \%$ and total sugar content of $15,114 \%$. While the results of the analysis for organoleptic functional biscuit test is the highest value of taste preference obtained at 60 hours of fermentation which is 5.4 (like).
\end{abstract}

Keywords: corn rice, fermented, biscuits, dissolved protein, total sugar

\begin{abstract}
ABSTRAK
Telah dilakukan penelitian tentang kadar protein terlarut dan gula total biskuit fugsional beras jagung fermentasi. Penelitian ini bertujuan untuk mengetahui waktu fermentasi yang memiliki kadar protein terlarut dan gula total tertinggi terhadap biskuit fungsional. Variasi waktu fermentasi untuk menentukan kadar protein terlarut dan gula total biskuit fungsional yaitu (12, 24, 36, 48 dan 60 jam). Diperoleh hasil analisis perlakuan yang terbaik terhadap biskuit fungsional adalah pada waktu fermentasi selama 60 jam dengan kadar protein terlarut 2,274\% dan kadar gula total $15,114 \%$. Sedangkan hasil analisis untuk uji organoleptik biskuit fungsional yaitu nilai kesukaan rasa tertinggi diperoleh pada waktu fermentasi selama 60 jam yaitu 5,4 (suka).
\end{abstract}

Kata Kunci: beras jagung, fermentasi, biskuit, protein terlarut, gula total 


\section{LATAR BELAKANG}

Tanaman jagung (Zea mays I) atau juga dikenal dengan nama maize merupakan sejenis rumput-rumputan yang berasal dari Meksiko hasil evolusi dari tanaman rumput liar Teosinte (Zea mays sp. Mexciana) (Johnson, 1991). Biji jagung mengandung protein sebanyak 7,9\% (Rahayu dan Djaafar, 2001). Kandungan kadar gula sederhana jagung berkisar antara 1-3\% (Suarni, 2007). Senyawa yang terdapat dalam jagung yaitu senyawa antinutrisi berupa asam fitat sebanyak 0,83 - 2,22\% yang menyebabkan protein sukar diserap sehingga dibutuhkan suatu cara untuk menghilangkan keberadaan asam fitat tersebut, salah satunya dengan melakukan proses fermentasi (Mizwar, 2012). Pada saat fermentasi mikroba yang tumbuh akan menghasilkan enzim fitase dalam jumlah besar yang mampu menghidrolisis asam fitat menjadi monofosfatanorganik, mioinositol fosfat rendah dan mio-inositol, sehingga penghilangan kandungan asam fitat ini dapat meningkatkan daya cerna protein yang terkandung didalam bahan pangan tersebut (El-Hag et al., 2002).

Hasil olahan pangan dari jagung dapat berupa beras jagung instan atau beras jagung termodifikasi. Proses pengolahan jagung menjadi beras jagung yaitu melalui penggiling secara tradisional untuk memecah biji jagung menjadi bentuk beras. Beras jagung didominasi bagian endosperm keras saja (Sharma et al., 2008). Komposisi endosperm pada biji jangung mencapai yaitu sekitar $85 \%$ dan didominasi oleh senyawa kelompok karbohidrat padai bagian lunak dan keras (Wilson, 1981). Komposisi kimia jagung berdasarkan bobot kering, endosperm memiliki protein 8,0\% dan gula 0,62\% (Inglett, 1987). Menurut Sugiyono et al. (2004), produk beras jagung instant yang dapat dimasak dalam waktu 46 menit serta memiliki umur simpan 12,613,4 bulan dalam kemasan aluminium foil. Beras jagung instant yang dihasilkan memiliki kandungan gizi yang terutama pada kandungan serat dan protein.

Masyarakat pedesaan secara tradisional telah mengenal dan menggunakan tepung jagung dalam pembuatan berbagai produk olahan makanan. Olahan pangan dalam bentuk tepung memilik penggunaan yang luas untuk berbagai bahan pangan (Aini et al., 2016). Tepung menjadi olahan alternatif setengah jadi yang tahan pada penyimpaan, mudah dicampur, diperkaya zat gizi (difortifikasi), mudah dibentuk dan lebih cepat dimasak (Claudia et al., 2015). Penambahan beberapa jenis mikroba yang tidak pathogen pada tepung dapat memperbaiki kualitas tepung, seperti penambahan bakteri asam laktat pada tepung akan meningkatkan pengembangan roti (Gerez et al., 2006). Menurut Aini et al. (2016), tepung jagung memiliki kadar protein terlarut $2,48 \%$. Sedangkan dari penelitian Aprilliani et al. (2013), sifat fisik dan kimia serta sifat fungsional terbaik adalah tepung jagung yang dihasilkan dengan menggunakan Lactobacillus casei selama 3 hari, dimana kadar protein terlarut 2,48\%. 
Olahan pangan yang cukup banyak diminati adalah produk biskuit yang dibuat dari tepung terigu (Gracia et al.., 2009). Widyastuti et al. (2015) melaporkan bahwa pada pembuatan biskuit dengan perlakuan rasio ubi jalar terhadap tepung jagung fermentasi 70 : 30 dan konsentrasi kuning telur $9 \%$ mempengaruhi kadar protein dalam biskuit, yaitu 3,5\%. Hasil penelitian Ratna et al. (2014), kandungan gizi tepung jagung yang dibuat dengan perendaman ragi tape $1 \%$ memiliki kadar protein $8,41 \%$. Penggunan perendaman dalam ragi tape menghasilka tepung jagung yang dihasilkan lebih putih, lebih halus dan aromanya lebih baik. Berdasarkan uraian tersebut diatas maka perlu dilakukan penelitian untuk waktu fermentasi beras jagung terhadap kadar protein dan total gula tertinggi biskuit fungsional.

\section{METODE PENELITIAN}

\section{Bahan dan Alat}

Bahan yang digunakan dalam penelitian ini adalah beras jagung, ragi $1 \%$, akuades, bahan pembantu dalam pembuatan biskuit seperti margarin, susu skim, gula, baking powder, telur dan garam. Bahan kimia yang digunakan adalah $\mathrm{NaOH} 1$ M, alkohol 80\%, $\mathrm{NaOH} \quad 0,1 \mathrm{~N}$, $\mathrm{Pb}\left(\mathrm{CH}_{3} \mathrm{COO}\right)_{2}, \mathrm{Na}_{2} \mathrm{C}_{2} \mathrm{O}_{4}$, glukosa, anthrone dan kertas saring whatman.

Alat yang digunakan pada penelitian ini adalah wadah, blender, belanga, sendok makan,neraca analitik, mixer, alat pencetak biskuit, oven, ayakan 60 mesh, pipet tetes, spektrofotometri UV-VIS, penangas air dan alat gelas yang umum digunakan dalam laboratorium kimia.

\section{Prosedur Penelitian}

\section{Pembuatan Tepung Beras Jagung Fer- mentasi (Widyastuti et al., 2015)}

Beras jagung yang diperoleh dari pasar Masomba Palu ditimbang sebanyak 1 kg dibersihkan dari kotoran dan kemudian dicuci berkali-kali hingga bersih dan ditiriskan, ditambahkan aquades dingin yang telah direbus sebelumnya dengan perbandingan 1:2 (b/v), kemudian ditambahkan ragi tape $1 \%$, difermentasi dengan variasi waktu (12, 24, 36, 48 dan 60 jam) pada suhu ruang $32 \pm 3^{\circ} \mathrm{C}$. Setelah fermentasi selesai maka beras jagung dipisahkan dari air sisa fermentasi dan kemudian dicuci hinggah bersih dan tidak berbau asam, ditiriskan dan dikeringkan dalam oven pada suhu $60^{\circ} \mathrm{C}$ selama $6 \pm 1$ jam, selanjutnya beras jagung digiling menggunakan blender dan diayak menggunakan ayakan 60 mesh.

\section{Pembuatan Biskuit Fungsional (Nurdjanah et al., 2014)}

Telur sebanyak 2 biji dihomogenkan kemudian dicampur dengan $38 \mathrm{~g}$ gula, $4 \mathrm{~g}$ susu skim, $26 \mathrm{~g}$ margarin dan dihomogenkan menggunakan mixer selama 3 menit, ditambahkan tepung beras jagung fermentasi sedikit demi sedikit sebanyak 100 g. Selanjutnya dilakukan penambahan 0,80 $\mathrm{g}$ baking powder dan $2 \mathrm{~g}$ garam, dicetak menggunakan cetakan dengan diameter $4,5 \mathrm{~cm}$ dan tebal $0,3 \mathrm{~cm}$, kemudian dipanggang menggunakan oven sampai matang. 
Analisa Kadar Protein Terlarut (Rohman dan Sumantri, 2007 dalam Elfian, 2016)

Sampel ditimbang sebanyak 0,5 gram kemudian dimasukkan dalam erlenmeyer $250 \mathrm{~mL}$, ditambahkan $50 \mathrm{~mL} \mathrm{NaOH} 1 \mathrm{M}$. Campuran dikocok selama 30 menit disaring dan filtratnya ditampung. Filtrat yang diperoleh dimasukkan ke dalam labu ukur $50 \mathrm{~mL}$, selanjutnya ditetapkan volumenya dengan akuades. Filtrat diukur absorbansinya pada panjang gelombang 260 $\mathrm{nm}$ dan panjang gelombang $280 \mathrm{~nm}$. Kadar protein terlarut dihitung menggunakan rumus :

Kadar protein $\%=$

$\underline{\text { A280 } \times \text { Faktor koreksi } \times \text { Faktor Pengenceran } \times \mathrm{V} \mathrm{NaOH}} \times 100$ Berat sampel $(\mathrm{mg})$

\section{Analisis Gula Total Dengan Metode Anthron (Sudarmadji et al., 1997)}

Sampel hasil penelitian ditimbang sebanyak $4 \mathrm{~g}$, kemudian ditambahkan alkohol $80 \%$ dengan perbandingan 1:1 ke dalam gelas kimia dan disaring menggunakan kertas saring whatman. Filtrat diukur pH-nya, jika asam ditambahkan $\mathrm{NaOH} 0,1 \mathrm{~N}$ sampai cukup basa ( $\mathrm{pH}$ sekitar 9). Larutan dipanaskan pada penangas air suhu $100^{\circ} \mathrm{C}$ selama 30 menit, larutan disaring kembali, selanjutnya campuran dipanaskan pada suhu $\pm 85^{\circ} \mathrm{C}$ hingga larutan bebas alkohol. Jika terdapat endapan, dilakukan penyaringan kembali. Filtrat dipindahkan ke dalam labu ukur 25 $\mathrm{mL}$, kemudian ditambahkan $3 \mathrm{~mL}$ timbal asetat $\left(\mathrm{Pb}\left(\mathrm{CH}_{3} \mathrm{COO}\right)_{2}\right)$ secara berhati-hati hingga larutan jernih, ditepatkan volumenya dengan akuades, dikocok hingga homogen dan disaring dengan kertas saring whatman. Filtrat ditambahkan natrium oksalat $\left(\mathrm{Na}_{2} \mathrm{C}_{2} \mathrm{O}_{4}\right)$ sebanyak $1 \mathrm{~g}$, dicampur sampai merata dan endapan yang terbentuk disaring menggunakan kertas saring whatman sehingga dinyatakan sebagai sampel.

\section{Pembuatan Kurva Standar Glukosa (Su- darmadji et al., 1997)}

Dipipet larutan glukosa standar 200 ppm sebanyak $0 ; 0,2 ; 0,4 ; 0,6 ; 0,8$ dan $1 \mathrm{~mL}$ ke dalam tabung reaksi, diencerkan sehingga total volume masing-masing tabung 1 $\mathrm{mL}$. Kemudian ditambahkan $5 \mathrm{~mL}$ pereaksi anthrone dengan cepat ke dalam larutan glukosa standar, ditutup dan dikocok hinggah merata. Selanjutnya tabung reaksi dipanaskan diatas penangas air $100^{\circ} \mathrm{C}$ selama 12 menit dan didinginkan. Larutan dipindahkan ke dalam kuvet dan diukur absorbansinya dengan spektrofotometri UVVIS pada panjang gelombang $630 \mathrm{~nm}$.

\section{Penetapan Sampel (Sudarmadji et al., 1997)}

Sampel yang telah dipersiapkan sebelumnya diambil dengan pipet mikro sebanyak $1 \mathrm{~mL}$ ke dalam tabung reaksi. Kemudian ditambahkan $5 \mathrm{~mL}$ pereaksi anthrone dengan cepat ke dalam larutan glukosa standar, ditutup dan dikocok hinggah merata. Selanjutnya tabung reaksi dipanaskan diatas penangas air $100^{\circ} \mathrm{C}$ selama 12 menit dan didinginkan. Larutan dipindahkan ke dalam kuvet dan diukur absorbansinya dengan spektrofotometri UV-VIS pada panjang gelombang $630 \mathrm{~nm}$. 
Gula total $=\frac{\mathrm{x} \cdot \text { Volume Filtrat.Fp }}{\mathrm{W}(\mathrm{mg})} \times 100 \%$

\section{HASIL DAN PEMBAHASAN}

\section{Kadar Protein Terlarut Beras Jagung Dan Tepung Beras Jagung Hasil Fer- mentasi}

Hasil yang diperoleh dari analisis protein terlarut beras jagung sebelum fermentasi yaitu $5,697 \%$. kandungan protein tinggi dalam jagung sangat penting untuk melengkapi nilai gizinya. Kandungan protein biji jagung pada umumnya $8-11 \%$, terdiri atas: albumin, globulin, prolamin, glutelin dan nitrogen nonprotein (Suarni, 2007). Pada penelitian Sugiyono et al. (2004), beras jagung instant memiliki kadar protein $11 \%$, sedangkan pada penelitian Nuraini et al. (2011) beras jagung instant yang dibuat dari tepung jagung putih tanpa perendaman dengan air memiliki kadar protein terlarut rata-rata $1,26 \%$ dan beras jagung instant yang dibuat dari tepung jagung putih dengan perendaman dengan air selama 24 jam memiliki kadar protein terlarut rata-rata $1,24 \%$. Pada proses pengolahan beras jagung instant, ada tahapan penggilingan dan pemasakan. Penggilingan adalah perlakuan fisik yang bertujuan untuk mereduksi ukuran partikel beras jagung, pengelupasan perikarp, pelepan tip cap dan lembaga. Hancur atau lepasnya bagian lembaga mengakibatkan pengurangan kandungan protein larut dalam air, tetapi protein tidak terbuang karena pemasakan tidak dilakukan hingga air habis. Berdasarkan hasil penelitian ini menyatakan bahwa kadar protein terlarut beras jagung lebih tinggi.

Hasil yang diperoleh dari analisis kadar protein terlarut tepung beras jagung fermentasi dengan variasi waktu $(12,24$, 36, 48 dan 60 jam) bertutut-turut yaitu $1,359 \%, \quad 1,545 \%, \quad 1,636 \%, \quad 1,7 \%$ dan 2,124\% (Gambar 1).

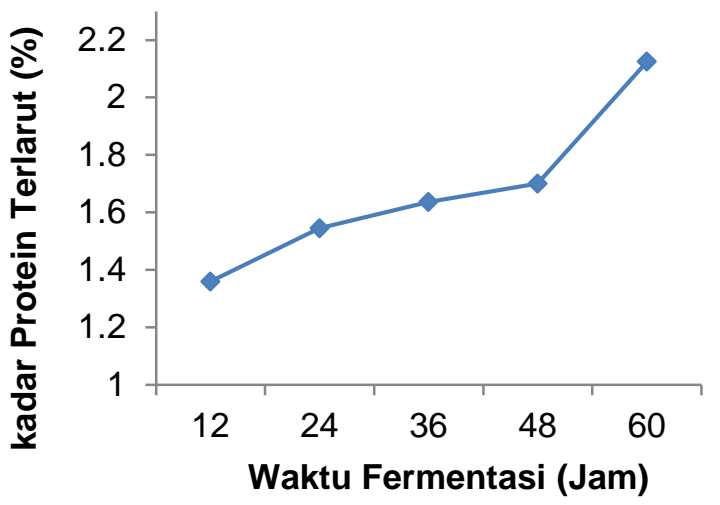

Gambar 1 Grafik hubungan antara waktu fermentasi terhadap kadar protein terlarut tepung beras jagung

Kadar protein terlarut tertinggi diperoleh pada waktu fermentasi 60 jam yaitu sebesar 2,124\% (Gambar 1). Kadar protein terlarut tepung beras jagung fermentasi berkisar antara 1,359\% sampai 2,124\%. Diperoleh bahwa kadar protein terlarut tepung setelah fermentasi berkurang. Selama proses fermentasi berlangsung menghasilkan enzim dan salah satunya yaitu enzim protease yang mendegradasi protein sehingga protein berkurang, namun semakin lama waktu fermentasi yang digunakan, semakin tinggi kadar protein terlarut dari tepung yang dihasilka, karena selama proses fermentasi terjadi perombakan seperti protein. Waktu fermentasi yang semakin lama akan meningkatkan asam 
laktat yang terbentuk (Aini et al.., 2016). Ragi tape memiliki beberapa kandungan mikroorganisme, diantaranya bakteri asam laktat, kapang dan khamir amilolitik, khamir non amilolitik, dan bakteri amololitik. Bakteri asam laktat dalm ragi tape memiliki fungsi untuk meghasilkan asam laktat (Astawan, 2004). Kadar protein terlarut meningkat akibat proses fermentasi yang semakin akan menyebabkan protein kompleks semakin banyak terhidrolisis menjadi asam amino bebas dan protein sederhana (Onweluzo dan Nwabugwu, 2009; Amadou et al., 2010). Oboh dan Elusiyan (2007) menyatakan bahwa proses fermentasi yang semakin lama akan menyebabkan biomassa mikroba akan semakin banyak yang diikuti dengan sekresi enzim ekstraseluler (protein terlarut) yang semakin banyak sehingga kadar protein terlarut meningkat.

Aini et al. (2016) melaporkan bahwa tepung jagung diproduksi melalui fermentasi dengan ragi tape menghasilkan kadar protein terlarut $1,63-2,23 \%$. Pada penelitian Lintang et al. (2013), karakteristik tepung jagung termodifikasi melalui proses fermentasi menggunakan ragi tape memiliki kadar protein terlarut berkisar antara 1,63 sampai $2,02 \%$. Lama fermentasi juga berpengaruh pada kadar protein terlarut tepung jagung termodifikasi yang dihasilkan. Semakin lama waktu yang digunakan maka akan semakin tinggi kadar protein terlarut dari tepung yang dihasilkan. Hal ini terjadi karena ragi lebih optimal menghdirolisis pati dan menghasilkan asam laktat. Namun apabila proses fermentasi ini tidak dihentikan, akan mempengaruhi rasa dan aroma dari tepung yang dihasilkan.

Berdasarkan hasil uji statistik anova untuk analisis sidik ragam menunjukkan bahwa waktu fermentasi tidak bebeda nyata terhadap kadar protein terlarut tepung hasil fermentasi. Sehingga tidak dilakukan analisis lanjut dengan uji Duncan $\alpha$ $=0,05$, karena signifikan $\geq 0,05$.

\section{Kadar Protein Terlarut Biskuit Beras Jagung Hasil Fermentasi}

Hasil yang dipeoleh dari analisis protein terlarut biskuit beras jagung fermentasi dengan variasi waktu $(12,24,36,48$ dan 60 jam) berturut-turut yaitu 1,405\%, $1,628 \%, \quad 1,744 \%, \quad 1,994 \%$ dan $2,274 \%$ (Gambar 2).

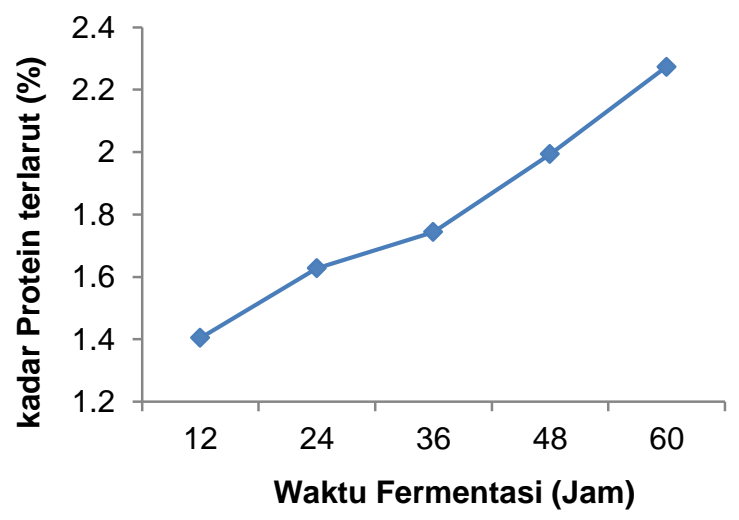

Gambar 2 Grafik hubungan antara waktu fermentasi terhadap kadar protein terlarut biskuit beras jagung

Kadar protein terlarut tertinggi diperoleh pada waktu fermentasi 60 jam yaitu sebesar $2,274 \%$, sedangkan kadar protein terlarut terendah terdapat pada waktu fermentasi 12 jam yaitu sebesar 1,405\% (Gambar 2). Semakin lama waktu fermen- 
tasi maka kadar protein terlarut yang dihasilkan semakin meningkat. Peningkatan kadar protein terlarut karena selama proses fermentasi terjadi perombakan seperti protein kompleks. Sumber protein pada pembuatan biscuit juga berasldari telur dan susu skim. Telur karena mengandung protein yang tinggi dan susunan asam amino yang lengkap dan seimbang (Achi, 2006). Sifat fungsional protein pada telur berperan menentukan kualitas produk akhir dalam industri pangan. Tujuan utama penambahan telur pada biskuit untuk memperbesar volume, memperbaiki tekstur, menambah protein yang dapat memperbaiki kualitas pada biskuit.

Berdasarkan uji statistik untuk analisis sidik ragam pada menunjukkan bahwa waktu fermentasi bebeda nyata terhadap kadar protein terlarut biskuit hasil fermentasi. Dilakukan analisis lanjut dengan uji Duncan $=0,05$ untuk menentukan kadar protein terlarut tertinggi pada waktu fermentasi terpilih. Hasil analisis lanjut dengan uji Duncan menunjukan terbentuknya 4 kolom subset dimana masingmasing kadar protein terlarut biskuit dari setiap taraf waktu fermentasi terletak pada kolom subset yang berbeda yang artinya berbeda nyata satu dengan yang lainnya.

\section{Kadar Gula Total Beras Jagung dan Te- pung Beras Jagung Hasil Fermentasi}

Hasil yang dipeoleh dari analisis kadar gula total beras jagung sebelum fermentasi yaitu 2,373\%. Kadar gula total pa- da jagung berkisar antara 1-3\%. Seiring dengan meningkatnya ketuaan biji jagung, kandungan gula menurun dan kadar pati meningkat (Suarni, 2011). Menurut Suarni (2005), kadar gula dalam 100 gram jagung kuning hibrida yaitu $1,20 \%$. Proses pengolahan dengan menghilangkan sebagian dari fraksi biji jagung akan mempengaruhi mutu gizi produk akhir. Komposisi kimia jagung berdasarkan bobot kering memiliki kadar gula yaitu $0,34 \%$ (biji utuh), 0,62\%(endosperma), 10,8\% (lembaga), 0,34\% (kulit ari) dan 1,6\% (tip cap).

Hasil yang diperoleh dari analisis gula total tepung beras jagung fermentasi dengan variasi waktu $(12,24,36,48$ dan 60 jam) berturut-turut yaitu 5,456\%, $7,029 \%, 8,045 \%, 9,835 \%$ dan $11,865 \%$ (Gambar 3).

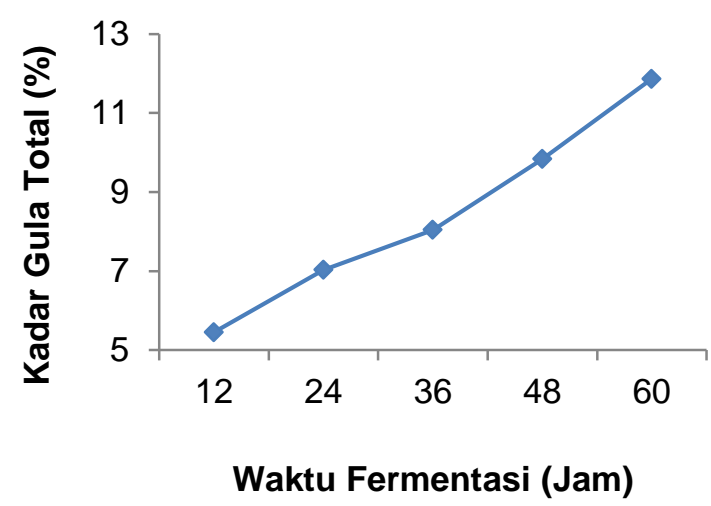

Gambar 3 Grafik hubungan antara waktu fermentasi terhadap kadar gula total tepung beras jagung

Kadar gula total tepung beras jagung fermentasi tertinggi diperoleh pada waktu fermentasi 60 jam yaitu sebesar 11,865\%, sedangkan kadar total gula terendah terdapat pada waktu fermentasi 12 jam yaitu sebesar 5,456\% (Gambar 3). Semakin lama waktu fermentasi maka kadar gula total 
yang dihasilkan semakin meningkat, karena selama proses fermentasi terjadi perombakan pati menjadi gula reduksi seperti monosokarida yaitu termasuk glukosa. Tepung jagung hasil fermentasi secara enzimatik memberikan perubahan fisikokimia, yaitu gula reduksi mengalami peningkatan dan teksturr tepung lebih halus dibanding (Richana et al.., 2007). Sacchromyces cereviciae dari sumber ragi yang merupakan enzim yang mampu menghidrolisis pati menjadi gula sederhana (Aini et al.., 2016). Rakkar (2007) juga melaporkan bahwa tepung jagung hasil fermentasi dengan ragi tape nenilik sifat fungsional yang lebih baik dibandingkan tepung jagung biasa. Peningkatan daya cerna pada bahan makanan terfermentasi disebabkan adanya pemecahan komponen komplek yang menjadi lebih mudah dicerna seperti gula, asam amino, asam lemak bebas dan juga adanya sintesis beberapa vitamin tertentu (Aini, 2013).

Berdasarkan uji statistik untuk analisis sidik ragam pada menunjukkan bahwa waktu fermentasi bebeda nyata terhadap kadar gula total tepung hasil fermentasi. Dilakukan analisis lanjut dengan uji Duncan $=0,05$ untuk menentukan kadar gula total tertinggi pada waktu fermentasi terpilih. Hasil analisis lanjut dengan uji Duncan menunjukan terbentuknya 5 kolom subset dimana masingmasing kadar gula total tepung dari setiap taraf waktu fermentasi terletak pada kolom subset yang berbeda yang artinya berbeda nyata satu dengan yang lainnya. Hasil analisis ragam dan hasil analisis uji lanjut menunjukan bahwa waktu fermentasi berbanding lurus dengan kadar gula total yang diperoleh.

\section{Kadar Gula Total Biskuit Beras Jagung Hasil Fermentasi}

Hasil yang diperoleh dari analisis gula total biskuit beras jagung fermentasi dengan variasi waktu $(12,24,36,48$ dan 60 jam) berturut-turut yaitu 10,537\%, $12,142 \%, \quad 13,349 \%, \quad 14,479 \%$ dan $15,114 \%$. Hubungan antara waktu fermentasi dan kadar gula total biscuit beras jagung ditunjukkan pada Gambar 4.

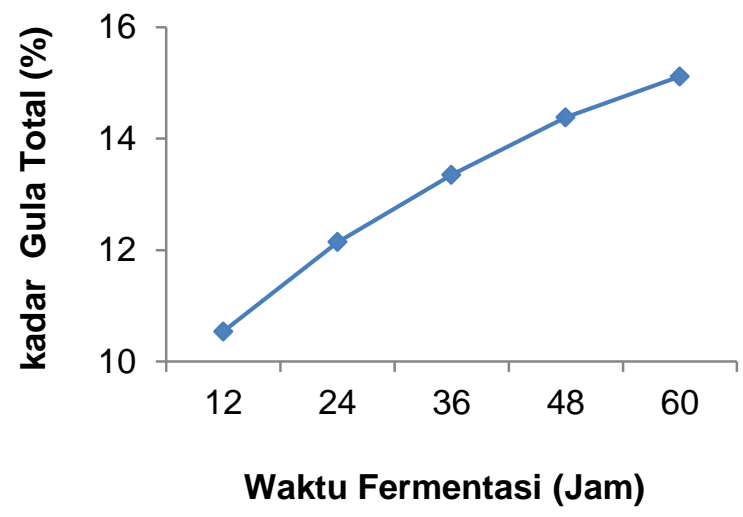

Gambar 4 Grafik hubungan antara waktu fermentasi terhadap kadar gula total biskuit beras jagung

Kadar gula total tertinggi diperoleh pada waktu fermentasi 60 jam yaitu sebesar $15,114 \%$, sedangkan kadar gula total terendah terdapat pada waktu fermentasi 12 jam yaitu sebesar 10,537\% (Gambar 4). Semakin lama waktu fermentasi maka kadar gula total yang dihasilkan semakin meningkat, karena selama proses fermentasi terjadi perombakan pati menjadi gula reduksi seperti mono- 
sokarida yang termasuk glukosa. Sacchromyces cereviciae yaitu sumber ragi yang merupakan enzim yang mampu dapat menghidrolisis pati menjadi gula sederhana (Aini et al.., 2016). Pada pembuatan biskuit terdapat zat tambahan lainnya seperti gula untuk menghasilkan cita rasa dan struktur biskuit yang baik, serta memberi rasa manis, melembutkan dan menghaluskan tekstur serta membuat warna kerak biskuit menjadi cokelat menarik.

Berdasarkan uji statistik untuk analisis sidik ragam pada menunjukkan bahwa waktu fermentasi bebeda nyata terhadap kadar gula total biskuit hasil fermentasi. Dilakukan analisis lanjut dengan uji Duncan $=0,05$ untuk menentukan kadar gula total tertinggi pada waktu fermentasi terpilih. Hasil analisis lanjut dengan uji Duncan menunjukan terbentuknya 5 kolom subset dimana masing-masing kadar total gula biskuit dari setiap taraf waktu fermentasi terletak pada kolom subset yang berbeda yang artinya berbeda nyata satu dengan yang lainnya. Hasil analisis ragam dan hasil analisis uji lanjut menunjukan bahwa waktu fermentasi berbanding lurus dengan kadar gula total yang diperoleh.

\section{Mutu Organoleptik}

Uji organoleptik atau sering juga disebut evaluasi sensori atau penilaian indera adalah pengukuran ilmiah yang bertujuan untuk mengukur, menganalisa karakteristik bahan pangan ataupun bahan lain yang diterima oleh indera penglihatan, penciuman, perabaan, pencicipan dan pendengaran serta menginterpretasikan reaksi dari hasil penerimaan proses penginderaan tersebut (Waysimah, 2010).

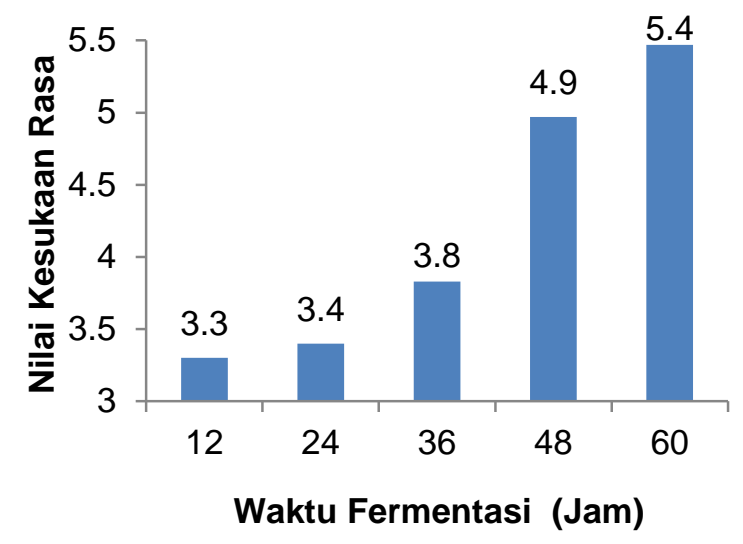

Gambar 5 Grafik hubungan antara waktu fermentasi terhadap nilai kesukaan rasa

Dari grafik yang diperoleh, 30 panelis didapatkan hasil bahwa rata-rata kesukaan panelis yaitu 5,4 (suka) (Gambar 5). Diketahui bahwa biskuit fermentasi selama 60 jam memiliki nilai yang paling tinggi dibandingkam dengan biskuit lainnya. Hal ini disebabkan karena pada waktu fermentasi selama 60 jam, dimana tepung beras jagung yang dihasilkan lebih baik karena waktu proses fermentasi selama 60 jam banyak mengandung gula pereduksi sehingga biskuit yang dihasilkan mempunyai kualitas dan karakterisitik lebih baik yang agak disukai panelis, dibandingkan dengan biskuit fermentasi selama 12 jam tepung beras jagung yang dihasilkan kurang baik sehingga mempengaruhi kualitas biskuit yang dihasilkan. Menurut Steinkraus (2002), makanan yang di fermentasi adalah substrat makanan yang ditumbuhi mikroorganisme yang dapat di- 
makan, terutama amylase, protease dan lipase yang menghidrolisis polisakarida, protein dan lemak menjadi produk dengan flavor, aroma dan tekstur menyenangkan dan menarik bagi konsumen.

\section{KESIMPULAN}

Berdasarkan hasil penelitian yang telah dilakukan dapat disimpulkan bahwa kadar protein terlarut biskuit fungsional beras jagung fermentasi tertinggi diperoleh pada waktu fermentasi 60 jam yaitu $2,274 \%$ dan kadarl gula total biskuit fungsional beras jagung fermentasi tertinggi diperoleh pada waktu fermentasi 60 jam yaitu 15,114\%. Hasil analisis untuk uji organoleptik biskuit fungsional yaitu nilai kesukaan rasa tertinggi diperoleh pada waktu fermentasi selama 60 jam, yaitu 5,4 (suka).

\section{DAFTAR PUSTAKA}

Achi dan N.S. Akomas, 2006. Comparative Assesment of Fermentation Techniques in The Pocessing of Futu, a Traditional Fermented Cassava Product. Pakistan Journal of Nutrition 5(3): 224-229.

Aini, N. 2013. Teknologi Fermentasi Pada Tepung Jagung. Yogyajakarta: Graha IImu.

Aini N., Gunawan Wijonarko dan Budi Sustriawan. 2016. Sifat Fisik, Kimia dan Fungsional Tepung Jagung Yang Diproses Melalui Fermentasi. agriTECH, 36(2).
Amadou, I., Mohamed, T., Kamara, T A., Foh, M B K., Guo-Wei, L. 2010. Physichochemical and nutritional analysis of fermented soybean protein meal by Lactobacillus plantarum Lp6. World Journal Dairy and Food Sciences, 5: 14-118.

Aprilliani, L., Aini, N., Wijonarko, G., Budiyanto. 2013. Karakteristik Tepung Jagung Termodifikasi Melalui Proses Fermentasi Spontan, Menggunakan Lactobacillus casei dan Ragi Tape. Jurnal Agroteknologi 7(2).

Astawan, M. 2004. Tetap Sehat Dengan Produk Makanan Olahan. Solo: Tiga Serangkai.

Claudia, R., Estiasih, T., Ningtyas, D W., Widyastuti, E. 2015. Pengembangan Biskuit dari Ubi Jalar Oranye (Ipomeae batatas L.) dan tepung jagung (Zea mays) Fermentasi: Kajian Pustaka. Jurnal Pangan dan Agroindustri, 3(4).

El-Hag ME, Abdullahi HET, Nabila EY, Elsiddiq AEE. 2001. Effect Of Natural Fermentation On Nutritive Value and Dehulling on Starch, Total Poliphenols, Phytic Acid Content and in Vitro Protein Digestibiliy o Pearl Millet. $J$ of Food Chem 77:93-196.

Elfian., Mappiratu., Razak, A R. 2016. Penggunaan Enzim Protease Kasar, Getah Biduri Untuk Produksi Cita Rasa Ikan Teri. KOVALEN 3(2): 122133.

Gerez, L.C., Rollan, G,C. dan Font de Valdes, G. 2006. Gluten Breakdown by Lactobacilli andpediococci Strains Isolated From Sourdough. Letters in Applied Microbiology 42 (5):459-464.

Gracia C, Sugiyono, Haryanto B. 2009. Kajian Formulasi Biskuit Jagung Dalam Rangka Subtitusi Tepung Terigu. J.Teknologi dan Industri Pangan 20(1):32-40. 
Inglett G. E. 1987. Kernel, Structure, Composition and Quality. Ed. Corn: Culture. Processing and Products. Westport: Avi Publishing Company.

Johnson, L. A. 1991. Corn: Production, Procesing and Utilization. Di dalam: Lorenz, K. J dan K. Kulp (eds.). Handbook of Cereal Science and Technology. New York: Marcell Dekker Inc.

Matorhasono, S. 1998. Biokimia. Jilid 1. Yogyakarta: Gadjah Mada University Press.

Mizwar. 2012. Isolasi dan Purifikasi Fitase dari Kotiedon Kedelai (Glycine max L. Merr) Hasil Perkecambahan. Jember: Pusat Penelitian Biologi Molekul dan akultas Pertanian Universitas Jember.

Oboh, G., dan Elusiyan, C A. 2007. Chamges in The Nutrient and Anti Nutrient Content of Micro-fungi Fermented Cassava Flour Produced from Low- and Mendium-Cyanide Variety of Cassava Tuber. African Journal of Biotechnology, 6: 1001-1005.

Onweluzo, J C. dan Nwabugwu, C C. 2009. Fermentation of Miller (Pennistum americanum) and Pigeon Pea (Cajanus cajan) Seeds for Flour Production: Effect on Compotition and Selected Functional Properties. Pakistan Journal of Nutrition, 8: 737-744.

Ratna Wylis Arief, Alvi Yani, Asropi dan Fatma Dewi. 2014. Kajian Pembuatan Tepung Jagung Dengan Proses Pengolahan Yang Berbeda. Banjarbaru: Balai Pengkajian Teknologi Pertanian (BPTP) Kalimantan Selatan.

Sharma V, Moreau RA dan Singh V. 2008. Increasing the value of hominy feed as coproduct by fermentation. App
Biochem and Biotechnol 149: 145153.

Nurdjanah, S., Astuti, S., Musita, N., Febriyaningsih, T. 2014. Sifat Sensory Biskuit Berbahan Baku Tepung Jagung Ternikstamalsasi dan Terigu. Jurnal Teknologi Industri dan Hasil Pertanian 19(2).

Steinkraus, K.H. 2002. Fermentation in World Food Processing Comprehensive Reviews in Food Science and Food Safety. 1:23-32.

Suarni dan I.U. Firmansyah. 2005. Beras Jagung: Proses dan Kandungan Nutrisi Sebagai Bahan Pangan Pokok. Prosiding Seminar dan Lokakarya Nasional Jagung.Makassar.393-398.

Suarni dan S. widowati. 2007. Struktur, Komposisi dan Nutrisi Jagung. Bogor: Balai Besar Penelitian dan Pengembangan Pascapanen Pertanian.

Sudarmadji, S., Haryono, B dan Suhardi. 1997. Prosedur Analisa Untuk Bahan Makanan dan Pertanian. Yogyakarta: Liberty.

Sugiyono, Soewarno T. Soekarto, Purwiyatno, H., Agus, S. 2004. Kajian Optimasi Teknologi Pengolahan Beras Jagung Instan. Jurnal Teknologi dan Industri Pangan 15: 119 - 128.

Waysima dan Adawiysh, D.R. 2010. Evaluasi Sensori. Bogor: Institut Pertanian Bogor.

Widyastuti, E., Claudia, R., Estiasih, T., Ningtyas, D W. 2015. Karakteristik Biskuit Bebasis Tepung Ubi Jalar Oranye (Ipomoeae batatas L.), Tepung Jagung (Zea mays) Fermentasi dan Konsentrasi Kuning Telur. Jurnal Teknologi Pertanian, 16(1). 
Wilson, C.M. 1981. Variations in soluble endosperm proteins of corn (Zea mays L.) in breeds as detected by disc gel electrophoresis. Cereal Chem. 58(5):401-408. 